\title{
PROSES PENGANGKATAN ANAK BEDA NEGARA MENURUT HUKUM DI INDONESIA
}

\author{
Ni Komang Ratih Kumala Dewi \\ Fakultas Hukum Universitas Mahasaraswati Denpasar \\ Email : ratih_kumala2001@yahoo.co.id
}

\begin{abstract}
ABSTRAK
Dalam setiap perkawinan tentunya mengharapkan seorang keturunan dengan tujuan untuk meneruskan keluarga selain itu sebagai pelengkap dalam sebuah perkawinan dan kesempurnaan bagi seorang wanita adalah menjadi ibu. Namun tidak banyak juga dalam sebuah perkawinan tidak dapat memiliki keturunan tentunya disebabkan dengan berbagai faktor. Kebanyakan dari pasangan suami istri yang sudah bertahun-tahun tidak memiliki keturunan memilih untuk melakukan pengangkatan anak atau adopsi. Dalam pengangkatan anak tidak jarang terjadi pengangkatan anak beda Negara seperti seorang warga Negara asing melakukan pengangkatan anak warga Negara Indonesia, terdapat juga dimana seorang warga Negara Indonesia melakukan pengangkatan anak warga Negara asing namun tentunya dalam pengangkatan anak tetap harus mengikuti prosedur hukum yang benar.
\end{abstract}

Kata Kunci : pengangkatan anak, warga Negara asing, warga Negara Indonesia, prosedur hukum

\section{ABSTRACT}

In every marriage is certainly expecting a descent in order to continue the family other than that as a complement in a marriage and completeness for a woman is to be a mother. But not many are in a marriage can not have children of course due to various factors. Most of the couples who have for years had no children chose to appoint a child or adoption. In adoption is not uncommon adoption of different countries as a foreign citizen commits adoption citizen of Indonesia, where there is also a citizen of Indonesia do adoptions foreign citizen but of course in the adoption must follow the correct legal procedures.

Keywords: adoption, foreign citizen, a citizen of Indonesia, a legal procedure

\section{Pendahuluan}

\section{Latar Belakang}

Setiap kehidupan manusia di dunia memang sudah menjadi kodratnya hidup berdampingan atau berpasangan dengan tujuan untuk membentuk sebuah keluarga yang terdiri dari suami, istri, dan pada umumnya seorang anak atau keturunan hasil dari perkawinan, adanya seorang anak memang untuk melanjutkan, menyambung estafet 
keturunan serta melestarikan harta kekayaan keluarga dan mempunyai seorang anak merupakan sebuah karunia yang indah serta sangat dibanggakan dalam sebuah keluarga. Dalam Undang-Undang Nomor 1 tahun 1974 Tentang Perkawinan, yang dimaksud dengan perkawinan adalah ikatan lahir batin antara seorang pria dan seorang wanita sebagai suami istri dengan tujuan membentuk keluarga atau rumah tangga yang bahagia dan kekal berdasarkan Ketuhanan Yang Maha Esa.

Anak merupakan harapan, bukan hanya harapan ayah ibu dan keluarga namun juga harapan bangsa, keinginan memiliki keturunan merupakan keinginan setiap manusia, kehadiran anak tidak hanya dipandang sebagai konsekuensi adanya hubungan biologis antara jenis kelamin lakilaki dan perempuan, tetapi lebih dari itu. Oleh karena itu rasanya kurang lengkaplah sebuah keluarga tanpa kehadiran seorang anak. Anak merupakan anugerah dari Tuhan Yang Maha Esa yang dalam dirinya melekat harkat dan martabat sebagai manusia seutuhnya (Saraswati, 2009). Oleh karena itu anak sebagai amanah dari Tuhan harus senantiasa dijaga dan dilindungi oleh keluarganya. Tetapi tidak semua keluarga dapat menikmati rasanya membesarkan seorang anak seperti keluarga lainnya. Didalam beberapa keluarga dimana menghendaki memperoleh seorang anak meskipun telah bertahun-tahun menikah tak kunjung dikaruniai anak, bahkan berbagi cara telah dilakukan baik itu dengan jalur medis maupun non medis, tetapi sekali lagi manusia hanya bisa berusaha tetap segala sesuatunya tetap Tuhan yang menentukan.

Pada kasus tertentu tanpa kehadiran seorang anak dalam sebuah perkawinan bagi seorang perempuan dianggap sebagai sesuatu yang tidak sempurna yang menimbulkan rasa kurang percaya diri bagi pasangan suami istri. Dalam keadaan demikian berbagai perasaan iri akan timbul dan pada keadaan tertentu tidak jarang perasaan dan pikiran tersebut berubah menjadi kecemasan. Kecemasan tersebut diekspresikan oleh salah satu pihak atau kedua pihak, dalam bentuk tindakantindakan tertentu. Salah satu tindakan suami istri, ketika keturunan berupa anak yang didambakan tidak diperoleh maka dilakukan langkah lain yaitu dengan cara mengambil alih anak orang lain selanjutnya, anak tersebut dimasukkan ke dalam anggota keluarganya sebagai pengganti anak yang tidak bisa diperoleh dari hasil perkawinan mereka. Cara memperoleh anak dengan cara ini, dalam istilah hukum Perdata Barat lazim disebut sebagai adopsi atau lebih kita kenal dengan anak angkat. Pengertian anak angkat menurut Undang-Undang Nomor 35 Tahun 2014 Tentang Perubahan Atas Undang-Undang Nomor 23 Tahun 
2002 Tentang Perlindungan Anak yaitu Anak yang haknya dialihkan dari lingkungan kekuasaan Keluarga Orang Tua, Wali yang sah, atau orang lain yang bertanggung jawab atas perawatan, pendidikan, dan membesarkan Anak tersebut ke dalam lingkungan Keluarga Orang Tua angkatnya berdasarkan putusan atau penetapan pengadilan. Sedangkan menurut Peraturan Pemerintah Nomor 54 Tahun 2007 Tentang Pelaksanaan Pengankatan Anak pengertian anak angkat yaitu anak yang haknya dialihkan dari lingkungan kekuasaan keluarga orang tua, wali yang sah, atau orang lain yang bertanggung jawab atas perawatan, pendidikan, dan membesarkan anak tersebut, ke dalam lingkungan keluarga orang tua angkatnya berdasarkan keputusan atau penetapan pengadilan.

Pengertian adopsi jika dilihat dari segi etimologi Adopsi berasal dari bahasa Belanda "Adoptie" atau Adoption (Bahasa Inggris) yang berarti pengangkatan anak. Pengertian adoptie menurut kamus hukum berarti pengangkatan seorang anak sebagai anak kandungnya (R. Tjitrosoedibio, 2008). Sedangkan Surojo Wignjodipuro, dalam bukunya Pengantar dan Asas-asas Hukum Adat mengatakan bahwa "Adopsi (mengangkat anak) adalah suatu perbuatan pengambilan anak orang lain ke dalam keluarga sendiri sedemikian rupa, sehingga antara orang yang memungut anak dan anak yang dipungut itu timbul suatu hukum kekeluargaan yang sama seperti yang ada antara orang tua dengan anak kandungnya sendiri" (Gumilar69,).

Pengangkatan anak menurut Peraturan Pemerintah Nomor 54 Tahun 2007 Tentang Pelaksanaan, pengangkatan Anak yaitu suatu perbuatan hukum yang mengalihkan seorang anak dari lingkungan kekuasaan orang tua, wali yang sah, atau orang lain yang bertanggung jawab atas perawatan, pendidikan dan membesarkan anak tersebut, ke dalam lingkungan keluarga orang tua angkat. Pengangkatan anak merupakan suatu perbuatan hukum karena harus melalui proses hukum dan adanya penetapan hakim di pengadilan. Pengangkatan anak yang dilakukan oleh beberapa pasang suami isteri bukan hanya berasal dari anak yatim piatu saja, ada juga yang melakukan pengangkatan anak terhadap anakanak di kalangan keluarga.

Jenis pengangkatan anak menurut Peraturan Pemerintah Nomor 54 Tahun 2007 yang diatur dalam Pasal 7 dimana pengangkatan anak terdiri dari pengangkatan anak antar warga Negara dan pengankatan anak antara warga Negara Indonesia dengan warga Negara asing. Proses pengangkatan anak antar warga Negara dapat diakukan berdasarkan hukum adat yang berlaku di daerah tertentu walaupun pada dasarnya haruslah tetap memerlukan suatu penetapan yang sah dari pengadilan untuk 
status anak angkat di kemudian hari. Sedangkan, pengangkatan anak terhadap warga negara Indonesia oleh warga negara Asing harus melalui Lembaga Pengasuhan Anak atau Yayasan Panti Asuhan yang ditunjuk oleh Departemen Sosial untuk melakukan Intercountry Adoption.

Pengangkatan anak warga negara Indonesia oleh warga negara Asing yang lebih dikenal dengan Intercounty Adoption, dimana dalam proses pengangkatan anak ini lebih sulit dan rumit dari pengangkatan anak pada umumnya. Calon anak angkat harus berada di lembaga pengasuhan anak, dengan kata lain anak yang akan diangkat oleh warga negara Asing tidak boleh diserahkan langsung oleh orang tua kandung si anak. Proses pengangkatan anak oleh Warga Negara Asing (Intercountry Adoption) tidaklah sama dengan proses pengangkatan anak antar warga negara Indonesia.

Semakin banyaknya jumlah anak-anak yang tidak memiliki orang tua terutama diIndonesia baik itu Karena di buang oleh orang tuanya atau sengaja ditelantarkan maupun karena orang tuanya meninggal dunia, hal inilah yang membuat banyak para dermawan ingin mengadopsi salah satu anak itu dan tidak bisa dipungkiri juga banyak WNA yang ingin mengadopsi anak WNI banyak faktor yang menyebabkan terjadinya hal ini salah satunya karena tidak memiliki keturunan maupun ingin membantu kesejahteraan anak, dengan mengadopsi anak itu bisa member kehidupan yang layak, pendidikan yang di butuhkan dan tentunya sebuah keluarga yang penuh dengan cintah kasih. Tapi tidak jarang juga anak warga Negara asing diangkat oleh warga Negara Indonesia. Berdasarkan latar belakang diatas sungguh sangat menarik sekali untuk diteliti lebih jauh lagi dan judul penelitian ini yaitu Proses Pengangkatan Anak Beda Negara Menurut Hukum Di Indonesia.

\section{Permasalahan}

1. Bagaimana proses pengangkatan anak warga Negara Indonesia oleh warga warga Negara asing menurut hukum di indonesia?

2. Bagaimanakah proses pengangkatan anak warga Negara asing oleh warga Negara Indonesia menurut hukum di indonesia?

\section{Pembahasan}

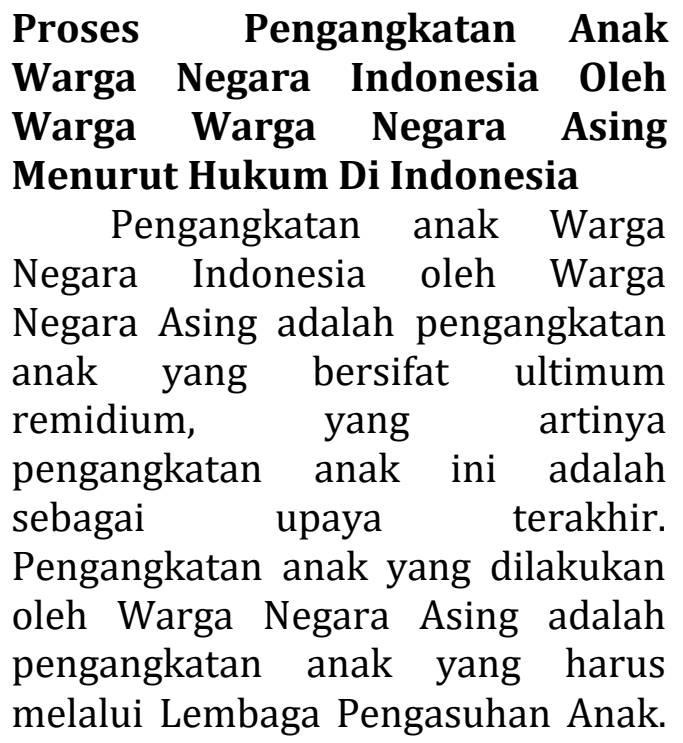


Didalam hukum adat pengangkatan anak atau adospi merupakan suatu perbuatan pengambilan anak orang lain ke dalam keluarga sendiri demikian rupa, sehingga antara orang yang memungut anak dan anak yang dipungut itu timbul suatu hubungan kekeluargaan yang sama seprti orang tua dengan anak kandung tentunya dan didalam proses pengangkatan anak harus dilakukan secara terang artinya wajib dilakukan degan upacara adat serta dengan bantuan kepala adat.

Dalam pengankatan anak atau adopsi tentunya didasarkan dengan berbagai alasan-alasan atau berbagai pertimbangan, adapun alsan- alsannya yaitu :

1. Untuk yang tidak mempunyai anak serta ingin mempunyai anak untuk mempertahankan garis keturunan/marga agar dapat menjaga dan memelihara kelak kemudian di hari tua.

2. Agar dapat mempertahankan ikatan perkawinan/kebahagia keluarga

3. Kepercayaan bahwa dengan adanya anak di rumah maka akan dpat mempunyai anak sendiri

4. Rasa belas kasihan terhadap anak terlantar atau anak yang orang tuanya tidak mampu memeliharanya atau demi kemanusian

5. Untuk mendapatkan teman bagi anaknya yang sudah ada

6. Untuk menambah atau mendapatkan tenaga kerja
7. Karena hanya mempunyai anak laki-laki maka diangkatlah seorang anak perempuan atau sebaliknya

8. Karena adanya hubungan keluarga atas permintaan orang tua kandung si anak kepada suatu keluarga agar anaknya dijadikan anak angkat (Meliala, 2016).

Pada dasarnya dalam pengangkatan anak alasan tertutama adalah takutnya tidak memiliki keturunan, kerena dalam sebuah perkawinan memperoleh kuturan atau memiliki keturunan merupakan Sesutu yang luar biasa dan tak ternilai harganya. Menjadi orang tua merupakan idaman semua orang yang sudah menikah karena tanpa keturunan hidup tidak akan sempurna.

Seperti yang dijelaskan dalam Pasal 12 PP Nomor 54 tahun 2007 Tentang Pelaksanaa pengangkatan anak ,syarat-syarat calon anak anagkat yaitu :

(1). Syarat anak yang akan diangkat meliputi :

a. Belum berusia 18 (delapan belas) tahun

b. Merupakan anak terlantar atau ditelantarkan

c. Berada dalam asuhan keluarga atau dalam lembaga pengasuhan anak

d. Memerlukan perlindungan khusus

(2). Usia anak angkat sebagaimana dimaksud 
pada ayat (1) huruf a meliputi :

a. Anak belum berusia 6 (enam ) tahun merupakan prioritas utama

b. Anak berusia 6 (enam) tahun sampai dengan belum berusia 12 (dua belas) tahun, sepanjang ada alas an mendesak dan

c. Anak berusia 12(dua belas) tahun sampai dengan belum berusia 18 (delapan belas) tahun, sepanjang anak memerlukan perlindungan khusus.

Dalam Pasal 13 PP Nomor 54 Tahun 2007 juga menentukan calon orang tua angkat harus memenuhi syaratsyarat :

a. Sehat jasmani dan rohani

b.Berumur paling rendah 30 (tiga puluh ) tahun dan paling tinggi 55 ( lima puluh lima) tahun

c. Beragama sama dengan agama calon anak angkat

d.Berkelakuan baik dan tidak pernah di hukum, karena melakukan tindakan kejahatan

e. Bersatatus menikah paling singkat 5 (lima) tahun

f. Tidak merupakan pasangan sejenis

g. Tidak atau belum mempunyai anak atau hanya memiliki satu orang anak

h.Dalam keadaan mampu ekonomi dan sosial i. Memperoleh persetujuan anak dan izin tertulis orang tua atau wali anak

j. Membuat pernyataan tertulis bahwa pengangkatan anak adalah demi kepentingan terbaik bagi anak, kesejahteraan dan perlindungan anak

k. Adanya laporan sosial dari pekerja sosial setempat

l. Telah mengasuh calon anak angkat paling singkat 6 (enam) bulan, sejak izin pengasuhan diberikan dan

m. Memperoleh izin menteri dan/atau kepala Instansi Sosial

Proses pengangkatan anak warga Negara Indonesia oleh warga Negara asing menurut hukum di Indonesia, sebagimana diatur dalam pasal 24 PP Nomor 54 Tahun 2007 yaitu Pengangkatan anak Warga Negara Indonesia yang dilahirkan di wilayah Indonesia maupun di luar wilayah Indonesia oleh Warga Negara Asing yang berada di luar negeri harus dilaksanakan di Indonesia dan memenuhi persyaratan sebagaimana dimaksud dalam Pasal 12 PP Nomor 54 Tahun 2007. Setelah itu kita bisa mengacu pada Pasal 14 PP Nomor 54 Tahun 2007 yaitu Pengangkatan anak Warga Negara Indonesia oleh Warga Negara Asing sebagaimana dimaksud dalam Pasal 11 ayat (1) huruf a, harus memenuhi syarat:

a. memperoleh izin tertulis dari pemerintah negara asal pemohon melalui kedutaan 


atau perwakilan negara
pemohon yang ada di
Indonesia;

b. memperoleh izin tertulis dari Menteri; dan

c. melalui lembaga pengasuhan anak.

Selain memenuhi syarat-syarat sebagia calon orang tua angkat seperti yang dijelaskan pada pasal 13 PP Nomor 54 Tahun 2007, terdapat juga syarat-syarat lainnya mengenai syarat calon orang tua angkat Warga Negara Asing yang diatur dalam Pasal 17 PP Nomor 54 Tahun 2007 yaitu adapaun syaratnya :

a. telah bertempat tinggal di Indonesia secara sah selama 2 (dua) tahun;

b. mendapat persetujuan tertulis dari pemerintah negara pemohon; dan

c. membuat pernyataan tertulis melaporkan perkembangan anak kepada untuk Departemen Luar Negeri Republik Indonesia melalui Perwakilan Republik Indonesia setempat.

Setelah permohonan pengangkatan anak warga Negara Indonesia oleh warga negera asing telah terpenuhi semua syarat-syarat lalu diajukannya ke pengadilan untuk mendapatkan putusan pengadilan dan pengadilan menyampaikan salinan putusan pengangkatan anak ke instansi terkait. Menurut Pasal 23 PP Nomor 54 Tahun 2007 Permohonan pengangkatan anak Warga Negara Asing di Indonesia oleh Warga Negara Indonesia berlaku mutatis mutandis. Selanjutnya mengenai tata cara pengangkatan anak menurut Pasal 46 Peraturan Mentri Sosial republik Indonesia Nomor 110/HUK/ 2009 Tentang Persyaratan Pengangkatan Anak , adapun tata cara pengangkatan anak WNI oleh WNA, Pasal 46 ayat (1) mengenai tata cara pengangkatan anak warga Negara indoensia oleh warga negar asing :

a. COTA mengajukan permohonan izin pengasuhan anak kepada Menteri Sosial diatas kertas bermaterai cukup dengan melampirkan semua persyaratan administratif CAA dan COTA sebagaimana dimaksud dalam Pasal 5 dan Pasal 45 ayat (1);

b. Menteri c.q. Direktur Pelayanan Sosial Anak menugaskan Pekerja Sosial Instansi Sosial untuk melakukan penilaian kelayakan COTA dengan dilakukan kunjungan rumah kepada keluarga COTA;

c. Direktur Pelayanan Sosial Anak atas nama Menteri Sosial cq Direktur Jenderal Pelayanan dan Rehabilitasi Sosial mengeluarkan Surat Keputusan Izin Pengasuhan Anak Sementara kepada COTA melalui Lembaga Pengasuhan Anak;

d. penyerahan anak dari Lembaga Pengasuhan Anak kepada COTA; 
e. bimbingan dan pengawasan dari Pekerja Sosial selama pengasuhan sementara;

f. COTA mengajukan permohonan izin pengangkatan anak disertai pernyataan mengenai motivasi pengangkatan anak kepada Menteri Sosial di kertas bermaterai cukup;

g. kunjungan rumah oleh Pekerja Sosial Departemen Sosial dan Lembaga Pengasuhan Anak untuk mengetahui perkembangan CAA selama diasuh COTA;

h. Direktur Pelayanan Sosial Anak membahas hasil penilaian kelayakan COTA, dan memeriksa serta meneliti berkas/dokumen permohonan pengangkatan anak dalam TimPIPA;

i. diterbitkannya Surat rekomendasi dari TIM PIPA tentang perizinan pertimbangan pengangkatan anak;

j. Menteri Sosial c.q. Direktur Jenderal Pelayanan dan Rehabilitasi Sosial mengeluarkan Surat Izin pengangkatan anak untuk untuk ditetapkan di pengadilan;

k. Apabila permohonan pengangkatan anak ditolak maka anak akan dikembalikan kepada orang tua kandung/ wali yang sah/kerabat, Lembaga Pengasuhan Anak, atau pengasuhan alternatif lain sesuai dengan kepentingan terbaik bagi anak;

l. setelah terbitnya penetapan pengadilan dan selesainya proses pengangkatan anak,COTA melapor dan menyampaikan salinan tersebut ke Departemen Sosial; dan

m. Departemen Sosial mencatat dan mendokumentasikan pengangkatan anak tersebut.

(2) Pengajuan pengangkatan anak ke pengadilan sebagaimana dimaksud dalam ayat (1) huruf j, dilakukan oleh COTA atau kuasanya dengan mendaftarkan permohonan pengangkatan anak ke pengadilan.

\section{Proses Pengangkatan Anak Warga Negara Asing Oleh Warga Negara Indonesia Menurut Hukum Di Indonesia}

Pengangkatan anak warga Negara asing oleh warga Negara indonesia memang tidak banyak kita jumpai atau kita temukan tetapi permasalah pengangkatan anak WNA oleh WNI itu ada atau pernah terjadi dan proses pengangkatan anak WNA dimana COTA mengikuti proses dan prosedur yang ditentukan oleh Negara dimana anak itu berasal. Berdasarkan Pasal 15 PP NO 54 Tahun 2007 menyatakan bahwa pengangkatan anak warga Negara asing oleh warga Negara Indonesia harus memenuhi syarat yaitu : 
a. Memperoleh persetujuan tertulis oleh dari Pemerintah Republik Indonesia

b. Memperoleh persetujuan tertulis dari pemerintah asal anak

Berdasarkan Pasal 37 Peraturan Menteri Sosial Republik Indonesia Nomor 11 /HUK/ 2009 Tentang Persyaratan Pengangkatan Anak menyatakan bahwa persyaratan COTA pada pengangkatan anak oleh COTA yang salah seorang Warga Negara Asing meliputi :

a. Persyaratan materil (Pasal 38)

Persyaratan materil :

1. sehat jasmani dan rohani baik secara fisik maupun mental mampu untuk mengasuh CAA

2. berumur paling rendah 30 (tiga puluh ) tahun dan paling tinggi 55 (limapuluh lima) tahun

3. beragama sama dengan agama calon anak angkat

4. berkelakuan baik dan tidak pernah dihukum karena melakukan tindak kejahatan

5. berstatus menikah secara sah paling singkat 5 (lima) tahun

6. tidak merupakan pasangan sejenis

7. tidak atau belum mempunyai anak atau hanya memiliki satu orang anak

8. dalam keadaan mampu secara ekonomi dan sosial

9. memperoleh persetujuan dari anak, bagi anak yang telah mampu menyampaikan pendapatnya dan izin tertulis dari orang tua/wali anak

10. membuat pernyataan tertulis di atas kertas bermaterai cukup yang menyatakan bahwa pengangkatan anak adalah demi kepentingan terbaik bagi anak, kesejahteraan dan perlindungan anak

11. membuat pernyataan tertulis di atas kertas bermaterai cukup yang menyatakan bahwa akan melaporkan perkembangan anak kepada Departemen Luar Negeri melalui Perwakilan RI setempat setiap tahun hingga anak berusia 18 (delapan belas) tahun

12. dalam hal CAA dibawa ke luar negeri COTA harus melaporkan ke Departemen Sosial dan ke Perwakilan RI terdekat dimana mereka tinggal segera setelah tiba di negara tersebut

13. COTA bersedia dikunjungi oleh perwakilan RI setempat guna melihat perkembangan anak sampai anak berusia 18 (delapan belas) tahun

14. adanya laporan sosial dari Pekerja Sosial Instansi Sosial Propinsi dan Lembaga Pengasuhan Anak

15. telah mengasuh calon anak angkat paling singkat 6 (enam) bulan,sejak izin pengasuhan diberikan 
16. melalui Lembaga Pengasuhan Anak

17. memperoleh persetujuan pengangkatan anak secara tertulis dari pemerintah negara asal suami atau istri melalui kedutaan atau perwakilan negara suami dan/atau istri yang ada di Indonesia

18. memperoleh rekomendasi untuk pengangkatan anak dari Kepala Instansi Sosial Propinsi

19. memperoleh izin pengangkatan anak dari Menteri Sosial untuk di tetapkan di pengadilan

b. Persyaratan administrasi (Pasal 39)

Persyaratan administratif ayat 1 :

1. surat keterangan sehat dari Rumah Sakit Pemerintah

2. surat keterangan Kesehatan Jiwa dari Dokter Spesialis Jiwa dari Rumah Sakit Pemerintah

3. copy akta kelahiran COTA

4. surat Keterangan Catatan Kepolisian (SKCK) setempat;

5. copy surat nikah/akta perkawinan COTA;

6. kartu keluarga dan KTP COTA;

7. copy akta kelahiran CAA;

8. keterangan penghasilan dari tempat bekerja COTA;

9. surat pernyataan persetujuan CAA di atas kertas bermaterai cukup bagi anak yang telah mampu menyampaikan pendapatnya dan/atau hasil laporan Pekerja Sosial;
10. surat izin dari orang tua kandung/wali yang sah/kerabat di atas kertas bermaterai cukup

11. surat pernyataan di atas kertas bermaterai cukup yang menyatakan bahwa pengangkatan anak demi kepentingan terbaik bagi anak dan perlindungan anak;

12. surat pernyataan tertulis di atas kertas bermaterai cukup yang menyatakan bahwa akan memperlakukan anak angkat dan anak kandung tanpa diskriminasi sesuai dengan hak-hak dan kebutuhan anak di atas kertas bermaterai cukup;

13. surat pernyataan tertulis di atas kertas bermaterai cukup yang menyatakan bahwa COTA akan memberitahukan kepada anak angkatnya mengenai asal usulnya dan orang tua kandungnya dengan memperhatikan kesiapan anak

14. membuat pernyataan tertulis di atas kertas bermaterai cukup yang menyatakan akan melaporkan perkembangan anak kepada Departemen Luar Negeri melalui Perwakilan RI setempat setiap tahun hingga anak berusia 18 (delapan belas) tahun

15. membuat surat pernyataan tertulis di atas kertas bermaterai cukup yang menyatakan bahwa dalam hal CAA dibawa ke luar negeri COTA harus melaporkan ke 
Departemen Sosial dan ke Perwakilan RI terdekat dimana mereka tinggal segera setelah tiba di negara tersebut;

16. membuat surat pernyataan tertulis di atas kertas bermaterai cukup yang menyatakan bahwa COTA bersedia dikunjungi oleh perwakilan RI setempat guna melihat perkembangan anak sampai anak berusia 18 (delapan belas) tahun 25

17. surat pernyataan dan jaminan COTA secara tertulis di atas kertas bermaterai cukup yang menyatakan bahwa seluruh dokumen yang diajukan adalah sah dan sesuai fakta yang sebenarnya

18. laporan sosial mengenai Anak dibuat oleh Pekerja Sosial Lembaga Pengasuhan Anak atau surat keterangan dari COTA mengenai kronologis anak hingga berada dalam asuhan mereka

19. surat penyerahan anak dari ibu kandung/wali yang sah/kerabat kepada COTA /rumah sakit /kepolisian / masyarakat yang dilanjutkan dengan penyerahan anak kepada Instansi Sosial

20. surat penyerahan anak dari Instansi Sosial Propinsi kepada Lembaga Pengasuhan Anak

21. surat keputusan kuasa asuh anak dari Pengadilan kepada Lembaga Pengasuhan Anak
22. laporan Sosial mengenai COTA dibuat oleh Pekerja Sosial Instansi Sosial Propinsi

23. surat keputusan Izin Asuhan dari Instansi Sosial Propinsi

24. laporan sosial perkembangan anak dibuat oleh Pekerja Sosial Instansi Sosial Propinsi

25. surat keputusan TIM PIPA tentang Pemberian Pertimbangan Izin Pengangkatan Anak

26. surat Izin Pengangkatan Anak yang dikeluarkan oleh Menteri Sosial untuk ditetapkan dipengadilan.

Ayat (2) Selain persyaratan sebagaimana dimaksud pada ayat (1) juga harus memenuhi persyaratan administrasi lainnya, yang meliputi :

1. rekomendasi dari instansi sosial propinsi

2. surat izin dari pemerintah negara asal suami dan/atau istri;

3. foto copy pasport dan Kartu Izin Tinggal Terbatas (KITAS) dan Kartu Ijin Tinggal Tetap (KITAP);

4. akte kelahiran suami dan/atau Istri Warga Negara Asing;

5. copy kutipan akte perkawinan/surat nikah yang dilegalisir di catatan sipil/KUA jika perkawinan di Indonesia dan di legalisir negara asal dikeluarkannya surat tersebut jika perkawinan di Luar Negeri; 
6. persetujuan dari keluarga suami atau Istri Warga Negara Asing yang dilegalisir dinegara asal dikeluarkannya surat tersebut;

7. surat keterangan catatan kepolisian dari Negara asal suami atau Istri Warga Negara Asing dan melaporkannya kepada Markas Besar Kepolisian Negara Republik Indonesia; dan

8. laporan sosial dari negara asal dimana COTA berdomisili.

Ayat (3) Persyaratan administratif COTA sebagaimana dimaksud dalam ayat (1), yang berupa copy harus dilegalisir oleh lembaga yang menerbitkan dokumen atau lembaga yang berwenang sesuai dengan peraturan perundang-undangan.

Serta Pasal 47 Peraturan Menteri Sosial Republik Indonesia Nomor 11 /HUK/ 2009 Tentang Persyaratan Pengangkatan Anak menyatakan bahwa :

Ayat (1) Pengangkatan anak Warga Negara Asing di Indonesia oleh Warga Negara Indonesia, harus memenuhi syarat:
a. memperoleh persetujuan tertulis dari pemerintah Republik Indonesia;
b. memperoleh persetujuan tertulis dari pemerintah negara asal anak; dan
c. COTA dan CAA harus berada di wilayah negara Republik Indonesia.

Ayat (2) Pelaksanaan pengangkatan anak Warga Negara Asing oleh Warga Negara Indonesia sebagaimana dimaksud pada ayat (1) harus memenuhi persyaratan dan prosedur yang ditentukan oleh negara anak dimana anak tersebut berasal.

Perlindungan terhadap anakanak di Indonesia termasuk anak angkat bertujuan untuk menjamin terpenuhinya hak - hak anak tersebut demi terwujudnya anak Indonesia yang berkualitas, berakhlak mulia, dan sejahtera. Seperti kita ketahui anak merupakan aset bangsa, penerus cita-cita bangsa, oleh karena itu penting bagi Pemerintah untuk dapat melindungi setiap hak-hak anak untuk dapat hidup tumbuh, berkembang, bebas dari kekerasan dan diskriminasi.

adapun hak-hak anak angkat yaitu :

a. Berhak untuk dapat hidup, tumbuh, berkembang dan berpartisipasi secara wajar sesuai harkat dan martabat kemanusiaan, serta mendapat perlindungan dari tindakan kekerasan dan diskriminasi.

b. Berhak atas suatu nama sebagai identitas diri dan status kewarganegaraan.

c. Berhak untuk beribadah menurut agamanya, berpikir dan berekspresi sesuai dengan tingkat kecerdasan dan usianya dalam bimbingan orang tua.

d. Berhak untuk mengetahui orang tuanya, dibesarkan, dan 
diasuh oleh orang tuanya sendiri.

e. Dalam hal karena sesuatu sebab orang tuanya tidak dapat menjamin tumbuh kembang anak, atau anak dalam keadaan terlantar, maka anak tersebut berhak diasuh atau diangkat sebagai anak asuh atau anak angkat oleh orang lain sesuai dengan ketentuan peraturan perundang - undangan yang berlaku.

f. Berhak memperoleh pelayanan kesehatan dan jaminan sosial sesuai dengan kebutuhan fisik, mental, spiritual dan social.

g. Berhak memperoleh pendidikan dan pengajaran dalam rangka pengembangan pribadinya dan tingkat kecerdasannya sesuai dengan minat dan bakatnya.

h. Setiap anak selama dalam pengasuhan orang tua, wali atau pihak lain manapun yang bertanggung jawab atas pengasuhan, berhak mendapat perlindungan dari perlakuan diskriminasi, eksploitasi baik ekonomi maupun aseksual, penelantaran, kekejaman, kekerasan penganiayaan, ketidakadilan serta perlakuan salah lainnya (Jurnal Sasi, Vol. 17 No.3).

Orang tua memang harus memiliki kesadaran bahwa melalui tangannyalah masa depan anakanak akan terbentuk. ketentuan yang mengatur tentang kewajiban dan tanggung jawab terhadap pengelolaan dan perlindungan anak angkat di Indonesia menjadi sangat penting. Komitmen pemerintah untuk memberikan perlindungan terhadap anak telah ditindaklanjuti dengan disahkannya Undangundang republik Indonesia Nomor 2003 tahun 2002 tentang Perlindungan Anak sebagaimana yang diatur pada Bab IV mulai pasal 20 sampai dengan pasal 26, menyangkut berbagai upaya yang dilakukan dalam rangka perlindungan, pemenuhan hak-hak dan peningkatan kesejahteraan anak. Salah satu solusi untuk menangani permasalahan anak dimaksud yaitu dengan memberi kesempatan bagi orang tua yang mampu untuk melaksanakan pengangkatan anak. Namun dalam Undang-undang ini persoalan anak angkat hanya dibahas dari segi definisi anak angkat dan tata cara pengangkatan anak serta sanksi bagi pelanggaran prosedur pengangkatan anak dan tidak ada pembahasan khusus mengenai persoalan pencatatan anak angkat.

\section{Penutup \\ Simpulan}

Berdasarkan pembahasan diatas maka dapat diperoleh kesimpulan dan saran yaitu

1. Proses pengangkatan anak warga Negara Indonesia oleh warga warga Negara asing menurut hukum di Indonesia yaitu sebagimana diatur dalam 
pasal 24 PP Nomor 54 Tahun 2007 yaitu Pengangkatan anak Warga Negara Indonesia yang dilahirkan di wilayah Indonesia maupun di luar wilayah Indonesia oleh Warga Negara Asing yang berada di luar negeri harus dilaksanakan di Indonesia dan memenuhi persyaratan sebagaimana dimaksud dalam Pasal 12 PP Nomor 54 Tahun 2007. Setelah itu kita bisa mengacu pada Pasal 14 PP Nomor 54 Tahun $2007 \quad$ yaitu Pengangkatan anak Warga Negara Indonesia oleh Warga Negara Asing sebagaimana dimaksud dalam Pasal 11 ayat (1) huruf a, selanjutnya terdapat juga syarat-syarat lainnya mengenai syarat calon orang tua angkat Warga Negara Asing yang diatur dalam Pasal 17 PP Nomor 54 Tahun 2007 dan terakhir Setelah permohonan pengangkatan anak warga Negara Indonesia oleh warga negera asing telah terpenuhi semua syarat-syarat lalu diajukannya ke pengadilan untuk mendapatkan putusan pengadilan dan pengadilan menyampaikan salinan putusan pengangkatan anak ke instansi terkait.

2. proses pengangkatan anak warga Negara asing oleh warga Negara Indonesia menurut hukum di Indonesia yaitu hukum di Indonesia tidak

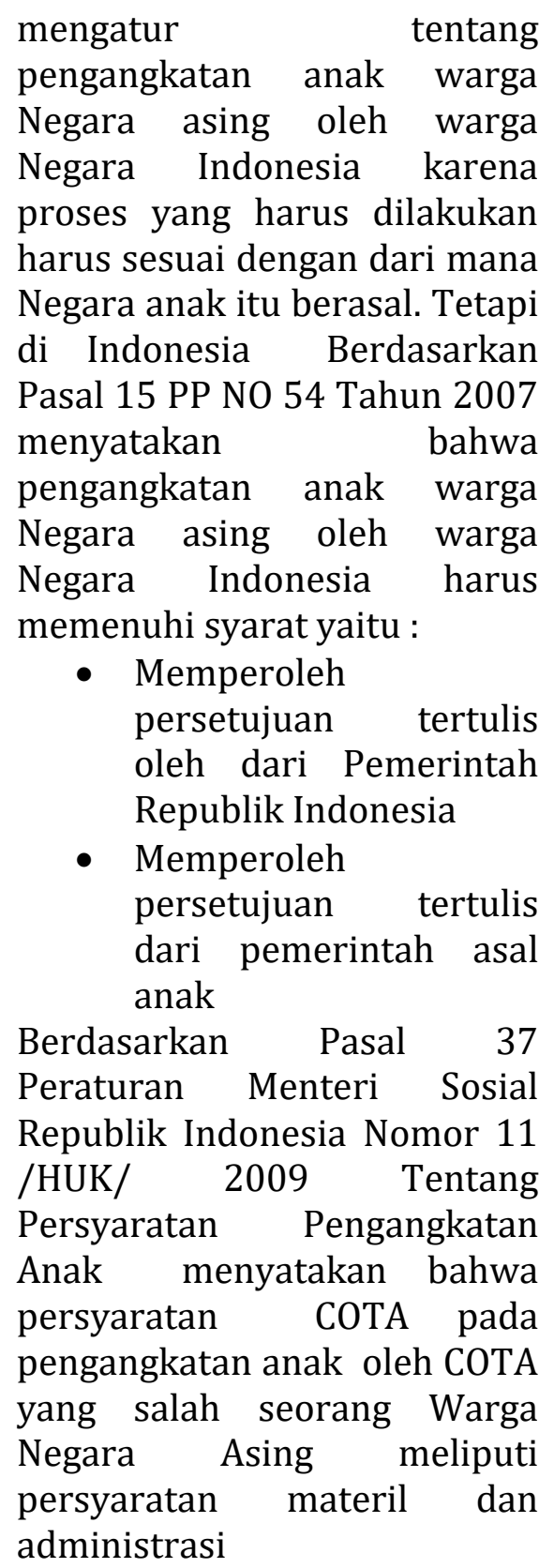

Saran

Bagi orang tua angkat diharapkan ketika melakukan pengangkatan anak wajib memperhatikan kesejahteraan serta hak-hak anak tidak boleh diabaikan karena hak anak ini merupakan 
bagian dari hak asasi manusia. Untuk pengangkatan anak, bagi calon orang tua anak yang mengadopsi anak wajib mematuhi aturan hukum yang berlaku di mana asal atau kewarganegaraan anak yang diadopsi tersebut. Pada saat sudah dilakukan pengangkatan anak yang berbeda negara, terkait tumbuh kembang anak tersebut wajib untuk dilaporkan kepada duta besar sebagai perwakilan Negara.

\section{Daftar Pustaka}

\section{Buku :}

Saraswati, 2009, Hukum

Perlindungan Anak di Indonesia, PT.Citra Aditya Bakti, Bandung.

R. Subekti, R. Tjitrosoedibio, 2008, Kamus Hukum, PT Pradnya Paramita, Jakarta

Djaja S.Meliala, 2016, Pengangkatan Anak (Adopsi) Berdasarkan Adat Kebiasaan Setempat dan Peraturan Perundangan Di Indonesia, CV Nuansa Aulia, Bandung

\section{Jurnal :}

Jean K. Matuankotta,Perlindungan Hukum Terhadap Anak Angkat dalam Memperoleh Kejelasan Status Hukum Melalui Pencatatan Pengangkatan Anak (Suatu Tinjauan dari Perspektif Hak Asasi Manusia), Jurnal Sasi, Vol. 17
No.3 Bulan Juli-September 2011

\section{Sumber Hukum :}

Undang-Undang Nomor 1 tahun 1974 Tentang Perkawinan, Lembaran Negara Republik Indonesia Tahun 1974 Nomor 1,Tambahan Lembaran Negara Republik Indonesia Nomor 3019

Undang-Undang Nomor 35 Tahun 2014 Tentang Perubahan Atas Undang-Undang Nomor 23 Tahun $2002 \quad$ Tentang Perlindungan Anak, Lembaran Negara Republik Indonesia Tahun 2014 Nomor 297, Tambahan Lembaran Negara Republik Indonesia Nomor 5606.

Peraturan Pemerintah Nomor 54 Tahun $2007 \quad$ Tentang Pelaksanaan Pengankatan Anak

Peraturan Mentri Sosial republik Indonesia Nomor 110/HUK/ 2009 Tentang Persyaratan Pengangkatan Anak

\section{Internet :}

Gumilar69, Makalah Hukum Tentang Adopsi ,https:// .blogspot.co.id/2013/06/makal ah-adopsi_14.html, diakses pada tanggal 30 Desember 2016. 